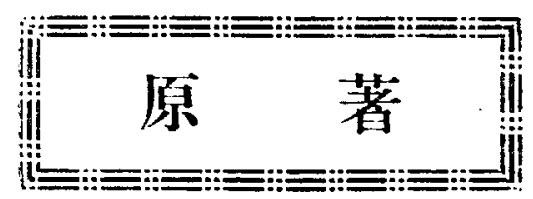

\title{
血液凝固に關する實驗的研究
}

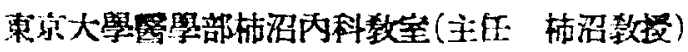

松网松三

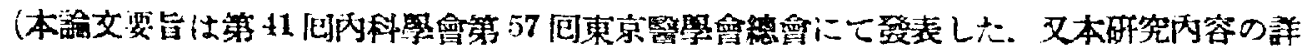

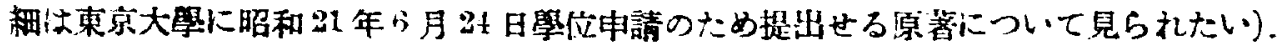

第1章 緦 点

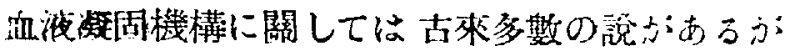

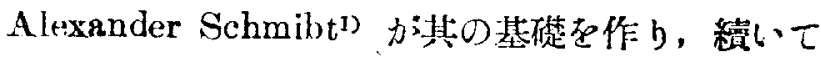
F(ammarsten ${ }^{2)}$, Morawitz ${ }^{3)}$ t經 $\tau$ Wöhlisch ${ }^{4)}$ に

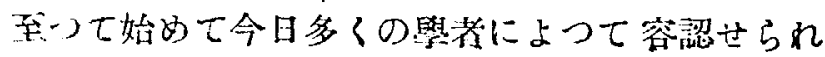

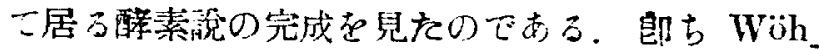
liseh に上ると，此の說の主踔は周知の如く次の 稼に總括せられて居る。血中る循環して居るプロ トロンビンがトロンボキナーゼ皮びカルシウムイ オンり作用によりトロンビンとなり，トロンビン カンフプリノーゲンに作用してフイブリンに變化 せしけると云うのである。此の一見理論整然たる 血液凝固镜も，個々の要素の本態站に作用機轉に 關しては何論䛕せられて居る所で，從つて此の點 に關する研究は非常に多いのであるか，著者は家 鬼に色々の苝物苍注入した時におこる血液凝国機

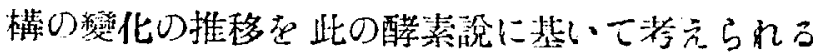
總一心耍秦について檢討した。

第 2 章 望驗方法

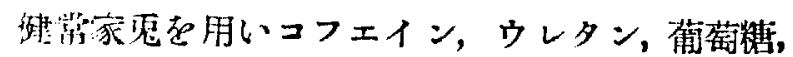
アトレレリン，ペプトン，モルフンの6種類の

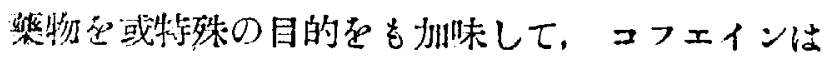

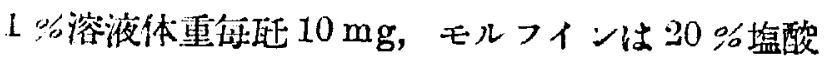
モル七亦溶液 $8 \mathrm{mg}$ ，ウレタンは10\%溶液 $0.5 \mathrm{gr}$,

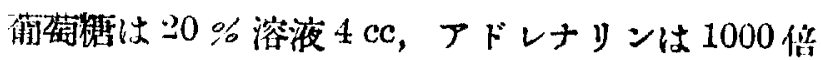

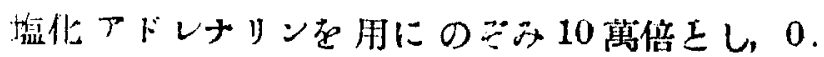

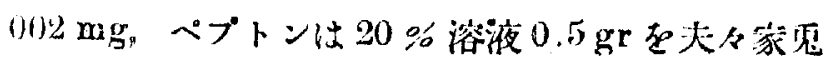

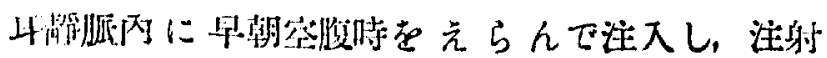

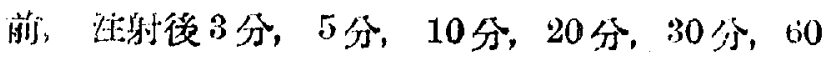

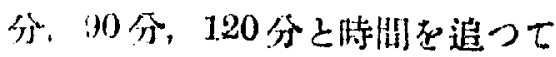

(1) 血液㠜固時間は，Sahli-Fonio 氏法 ${ }^{j)} に よ$ り攝纸吏度の恒溫水浴中にて著者の考案せる方 法により計測し.

（2）血清カルシウム量は，Kramer-Tisdall E

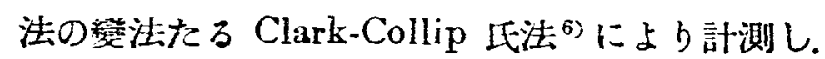

(3)フィブリノゲン及びトロンビン晕は，Wo. hlgenuth E法》に準㨜し，1回の探血量をなる ベく少店くするため少しく改良し，トロンビン量 は採血90分後に分離せる血清について計测し。

(4)プロトロンビン量は，Quick 氏法の變法 8) によりプロトロンビン時間を以てその值を示し。

（5）アンチトロンビン量は，Howell-Hess 氏

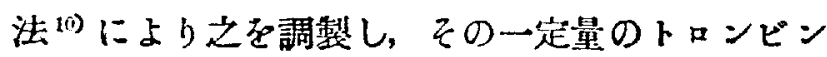
に對方る凝固抑制の程度を檢することにより計測 ᄂ.

（6）血小板數は，Fonio 氏法により計测した。 第 3 章 實驗成結

缔1節 コフェインの血液凝固に及济す影響

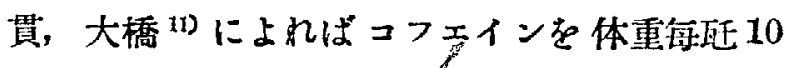
mg 定家象靜胍內に汪入する時は血压の上景を來

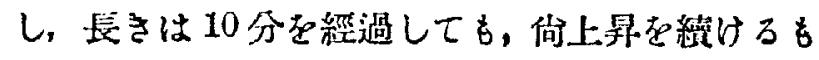
のありと云う。渚孝は此の事實に基いて，1\%コ

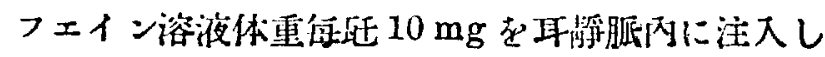
時間を追つて血液凝固機棈の變化の推移を調へた 結果血液㠜固時間は短䋨し，アンチトロンビン量

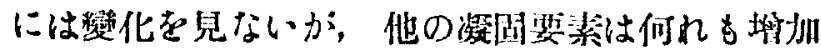

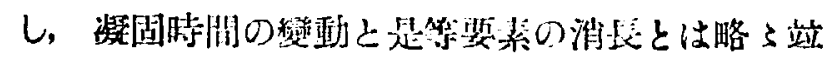
行することを知つた。（䟠略）

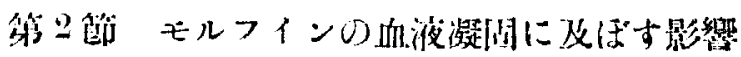

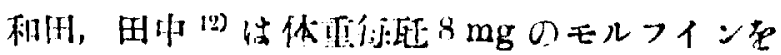




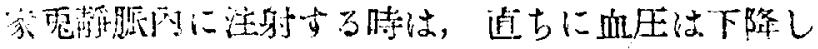

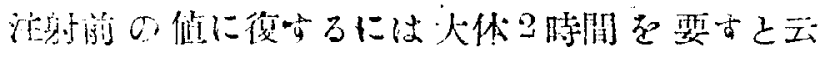

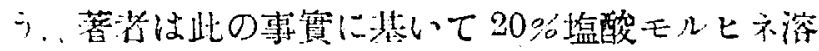

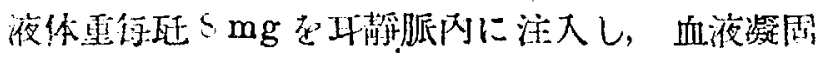

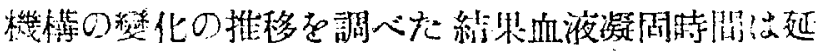
长し，アンチトロンビン琶の垉扣が見られる以外

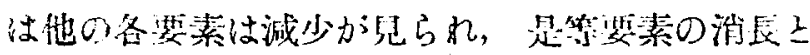

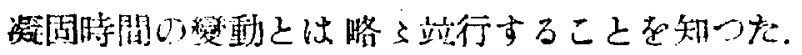
（表略）

第3 篩 惐萄糖の血液凝固に及ぼす影響

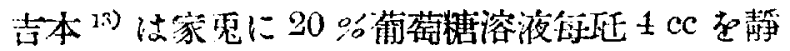
胍內に注入すると血在は上男し，約 6 分にして前 の血生に技古と云う，著者は之にならい20\%葡萄

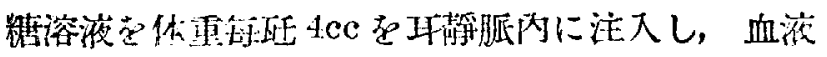

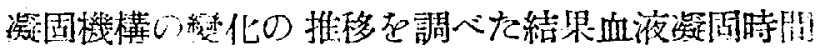
性短繀し，血声カルシウム量，トロンビン量の娍 少を思，フイブリノゲン量には絲化なく，血小板 教は却つて減少尼示すすの寧万多く，カルシウム， トロンビン，プロトロンビン，アンチトロンビン

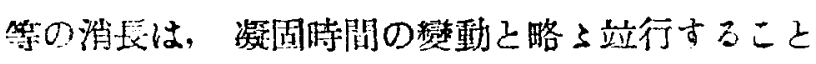
知つた。（表略）

第4節 ウレタンの血液凝固に及法す影響

貫，大橋，和田 ${ }^{11)}$ はウレタン体重安互 $0 . \overline{6} \mathrm{gr}$

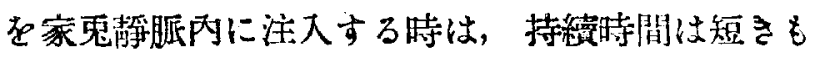
著明应血压下降を來すと云う，著者は此の事實に 基いて $10 \%$ ウレタン溶液短酉 $0.5 \mathrm{gr}$ 年靜胍队 に注入し，時間を追つて凝固機構の變化の推移を 調べた結果血液凝固時䦌は延長し，アンチトロン ビン量には變化を認めないが，他の各凝固垽素は 何れも減少し，是等凝固恶素の消長之血液凝固時

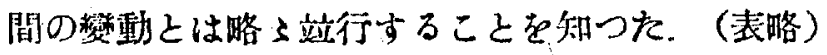

\section{第万節 アドレナリンの血液}

凝固に及汸与影響

アトレナリンの家腎血圧に及ぼす影響に關する

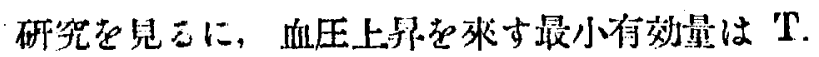

Biandet u A. Weckmann ${ }^{14)}$ は $0.01-0.03 \mathrm{mg}$, Lannoy et Mengny ${ }^{15)}$ は $0.0005-0.001 \mathrm{mg}$, 小

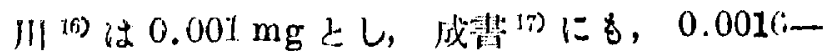

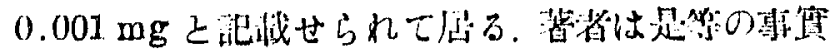
に其いて 1000 倍盟化アドレナリン(三其) 100倍

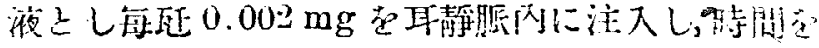

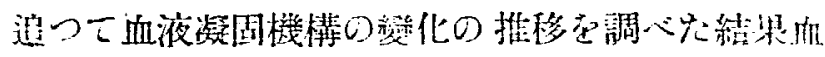

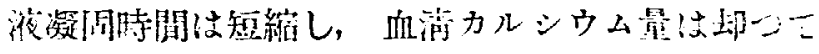

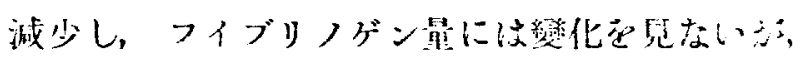

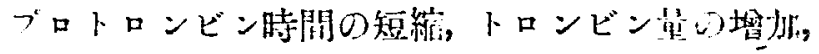

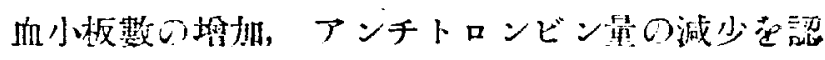
む，ブロトロンビン時周，トロンビン量，血小板

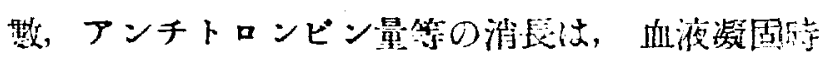

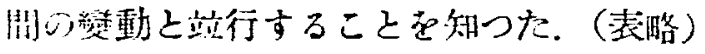

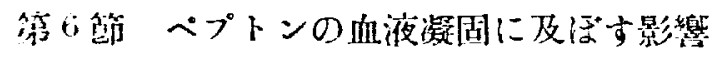

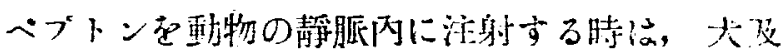

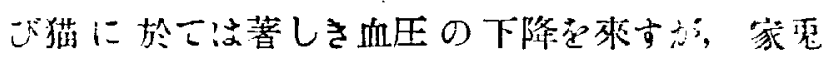

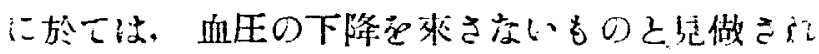

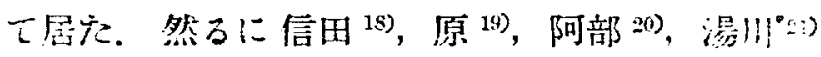

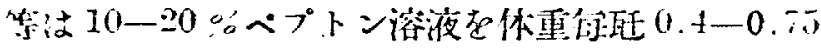

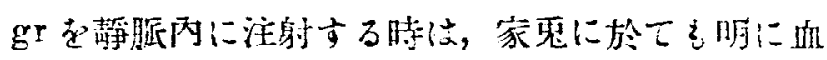

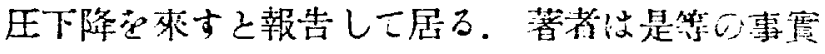

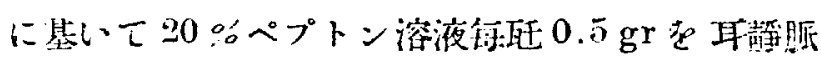
內に注入し，天の後時閏を追つて血液凝固機構心。

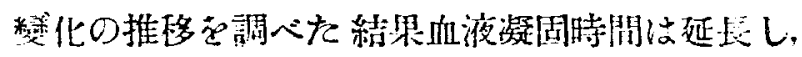
トロンビン量の減少, 血小板數の減少, プロトロ ンビン時間の延長，アンチトロンビン量の櫭加す

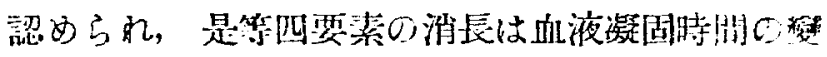
動上略与端行すること知つた（表略）

\section{第4售 總括及び䋹諭}

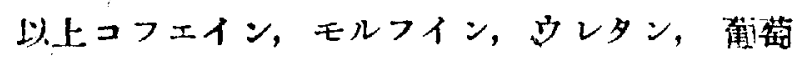
榶、アドレナリンペプトンの6 種の藥物に就て,

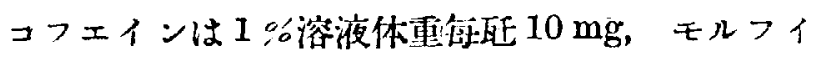
ンは $20 \%$ 塩酸モル七六溶液 $8 \mathrm{mg}$, ウレタンは10

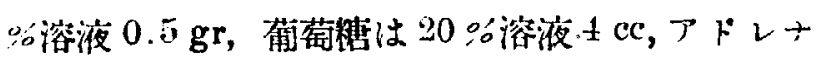
yンは10蕾倍塩化アドレナリン0.002mg, ペブト ンは $20 \%$ 溶液 $0.5 \mathrm{gr}$ 老々家鬼靜胍內に注入し

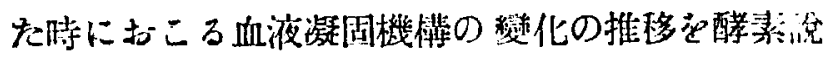
に些いて考えられる總ての要素に就て檢討した。 今前後の䋖動の此较を曲線をもつて示方と，大作

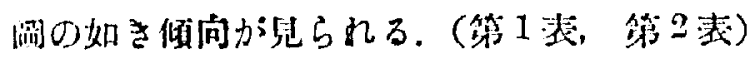

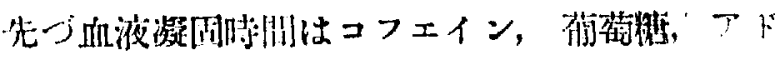
レナリン, ウレタンでは短絎，モルフインりレ

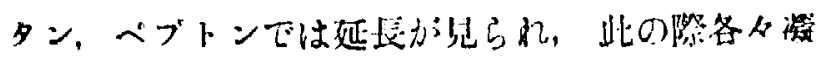

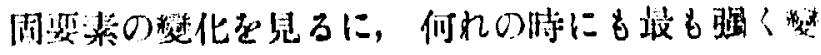


第 1 表

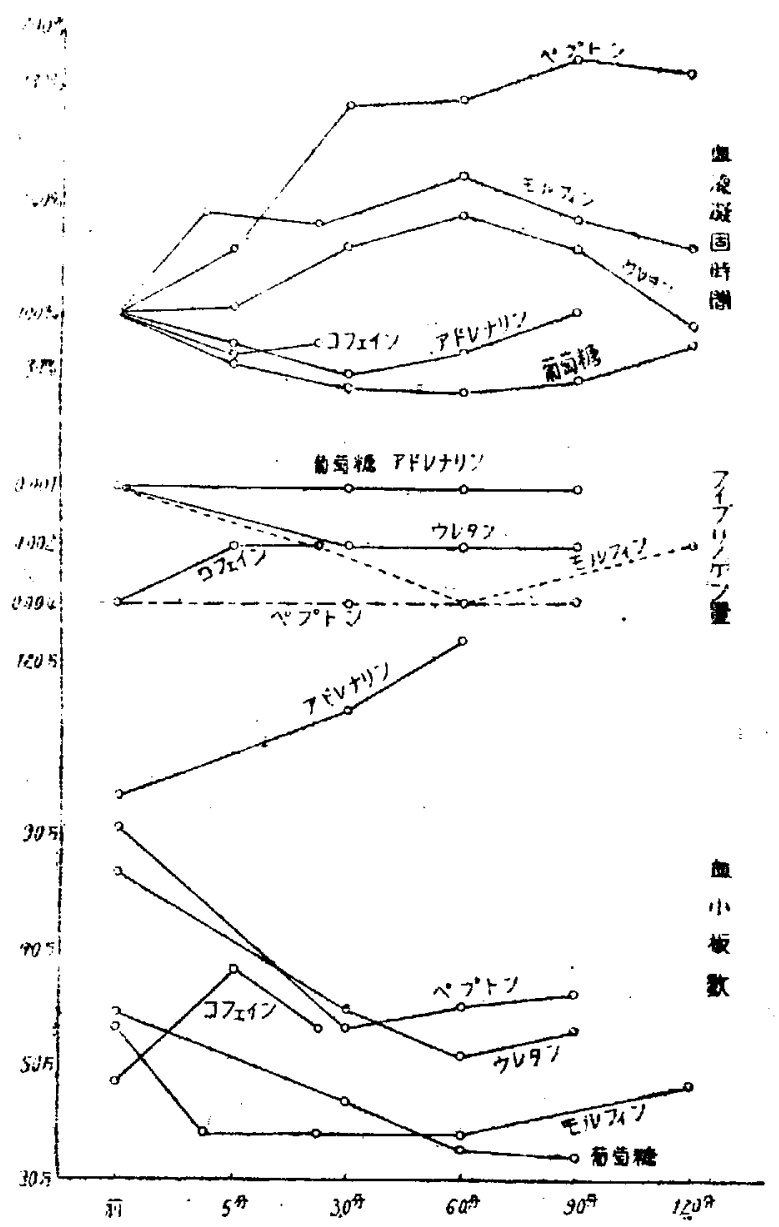

動するの仿，プロトロンビン量, トロンビン量, 血小小板數の三要素である。即ち是等か溜固機構中 で最も重大な 意味る有するるのであることる示す ちのてむる。份各要素の變動の推移を全讯的にな カ活る上，葡萄糖の㭙に血小板數の減少を示すを の器ら多く，アンチトロンビン量の娍少の傾向力: 思れ，アドレナリンの時にカルシウムの減少， アンチトロシビン量の減少の傾向が見られ, ヘプ トンモルフインの特にアンチトロンビン量の增

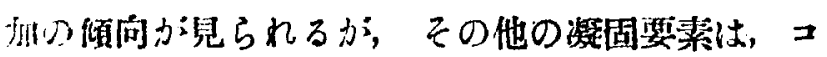

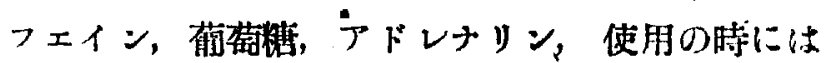
嵝列して居り，千ルフイン，ウレタンパプン

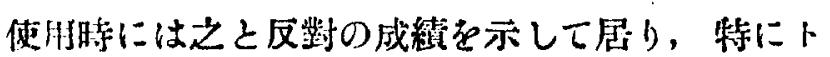
ロンビン量，プロトロンビン量，血小板数と云う

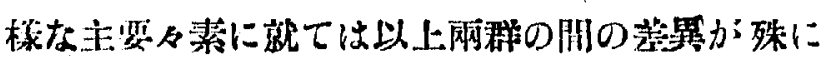
明か・あらわれて居るのである。

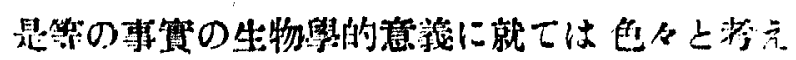

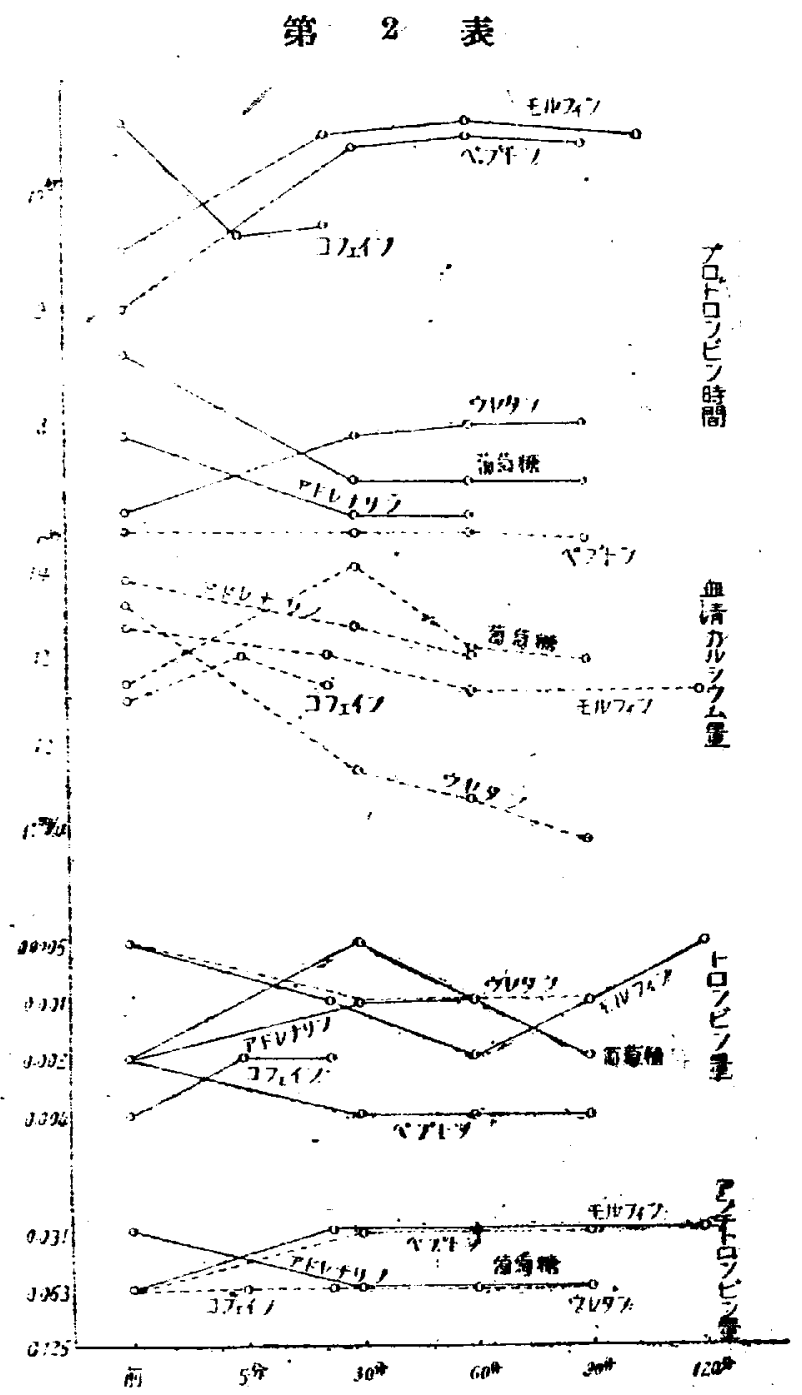

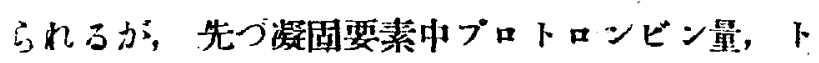
ロンビン量, アンチトロ゙ンビン量, フィプリノゲ ン量等重要なる゙のがアドレナリン葡萄傮使用の 時とペプトン使用の時と反教の成数を示すと云う ことなどを考えると，叶㖑が生体內での血液凝固 と云うことに閣與する引要椥器であると云う感し

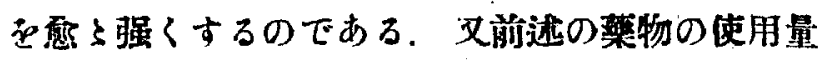

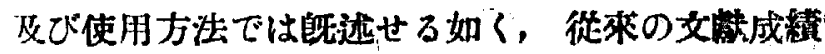

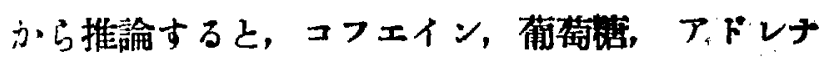
リンは血圧に高上的に作用し，モルフインすレ タン,ベプトン注反姃に低下的に㗢くのであるが，

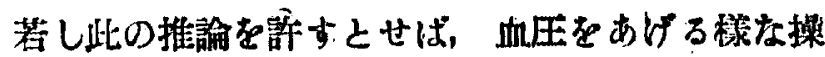

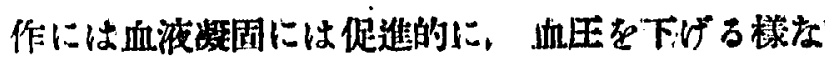

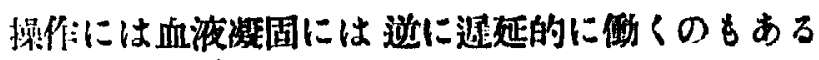

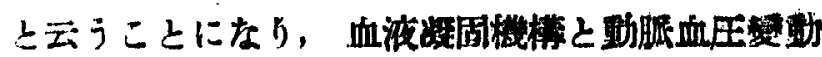


とつ凩にも一脈の聯閶のあることが推定せるれる のでする.

\section{文跃}

1) Schmibt A : Pfliugers Arch. 6. 445. 1892. 一2) Hammarsten. O: Pflügers Aroh. 19.536. 1896. -3) Morawitz. P : Hof meisfers. Beitrige. 5. 174. 1904. -4) Wöhliseh. E : Erg. d. Physiol 28. 443.
1929.-5) Fonio: Grenzgeb. d. Med u. Chir. 27. 644.1993, - -6) Cark-Collip: J. Biolchom. 6\%. 461.1925. -7) Wohlgemuth: Bioch Ztsehr. 25. 79.1910. -8) Quick A.J. Am. J. Physiol, 11\%,

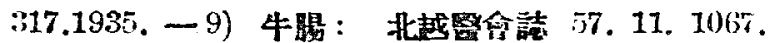
昭 17). - 10) Hess. Proc. Soc Exp. Biol Med. 19.39 .1914 .
(1)下畧)

\title{
皮䖉に於ける結核アレルギー現象の陽性率と植物种經 系統並に整規代謝との關係に就て
}

附・所謂ッ反應の陽性轉化は果して特發性肋膜桨登症の原因なりや

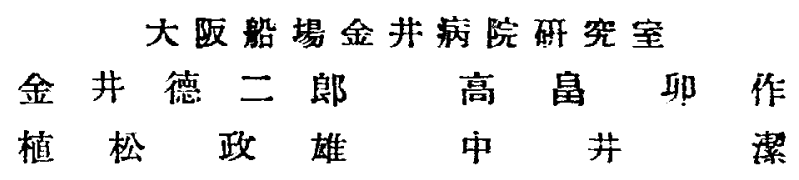

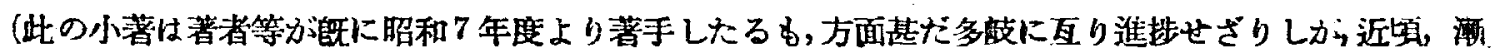
く其結論に到達しつ」ありし所に，不幸にして昭和20 年3月14日依間の空㜔に因り，病院遭危し研究

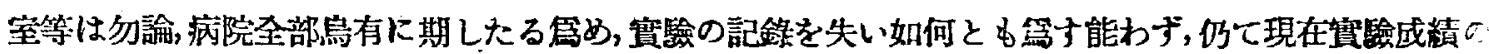

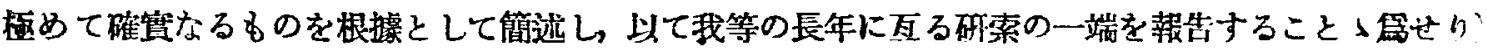

1. 序 浣

2. 實驗的研素

3. 成續の概括的批判

4. 結 論

1. 序說 アレルギー現象と冤疫力との關係に 就ては，諸家の論議一定せす，Kallos》等端に多 教の諸家はアレルギー現象は禾疫力之は道接の連 關(郎ち，免疫力の高度とアレルギー現象の强度と は站行せす，然れども或は未知の點に於て，一定 の連關を有するものなりとの見解に在りっ) 無しと

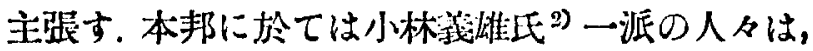
其の特發性肋膜炎(軍降胸膜炎)弡症に關する報告

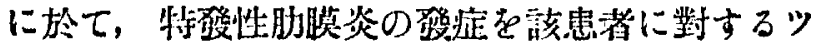
反礁の陽性喠化を以て根本的病因を第するのと し，氏等は軍㭬胸膜炎を以て，全部結核菌の感染 に基くものなり之結論せり，然るに虽時余等は特

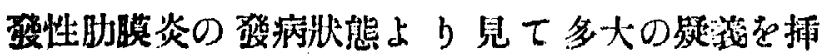

み，遂に實驗的に例外なく，金井 ${ }^{3)}$ 肋膜炎 を確認するに至り(原著參照)，愈与此の說に對し

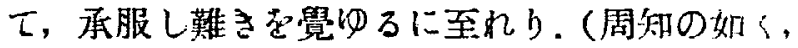
軍隊胸朕炎は多々の場合極めて懪發性に急激に变 生す)。爾來多方面上りする本症發症の道接症万起 炎病原の研案に從事し，其の都度之公表せり(原 著參照)。次でツ反應に關する實䲆に著手したる も，此の問題は其の研梁途上に於て，非常なる難關 に幾度か淔面し，逐に不識の間に永き年月の經過 經るに至れり，然るに䡺近に至りて，漸〈此の

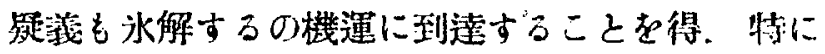

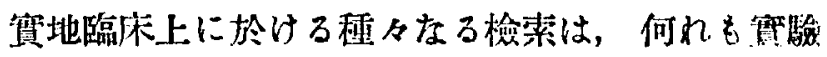
的硎究に於けるるのと全然整然をる一致在厉し， 些の撞靚なきことを猚認するに至れり。

更に我等は，此の研来の道程に於て，黄く㕅

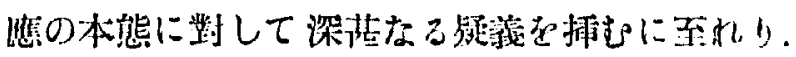

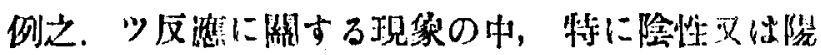

